\title{
Factors Influencing the Political Activity of Social Workers: A Comparative Study Among Swiss and United States Social Workers
}

\author{
Tobias Kindler ${ }^{1,2}$ and Jason Ostrander ${ }^{3}$ \\ ${ }^{1}$ Hebrew University of Jerusalem, Paul Baerwald \\ School of Social Work and Social Welfare \\ ${ }^{2}$ Eastern Switzerland University of Applied Sciences (OST), \\ School of Social Work, Institute of Social Work and Social Spaces \\ ${ }^{3}$ Sacred Heart University, School of Social Work
}

\begin{abstract}
Author Note
Tobias Kindler (10) https://orcid.org/0000-0001-6861-4162

Jason Ostrander (iD https://orcid.org/0000-0002-3141-2978

We have no known conflict of interest to disclose.

Correspondence concerning this article should be addressed to Tobias Kindler, Eastern Switzerland University of Applied Sciences, School of Social Work, Institute of Social Work and Social Spaces, Rosenbergstrasse 59, 9001 St.Gallen, Switzerland. Email: tobias.kindler@,ost.ch
\end{abstract}




\begin{abstract}
Various international and national social work ethical principles call social workers to participate in politics, yet not much research exists in the field of a political social work. Little is known about the actual voluntary political engagement of social workers as well as factors influencing their political activity. Especially, few studies with an international comparison focus have been conducted. Consequently, this study used cross sectional survey design to better understand the factors influencing the political activity of social workers in Switzerland $(n=1242)$ and in the United States $(n=3033)$. The results indicate that the political activity of social workers is strongly associated with the political influence of parents, with membership in a professional social work association as well as with political efficacy. There are some differences between Swiss and US social workers, mainly concerning the influence of memberships in trade unions. As one of few international practice comparison pieces, this article aims to further stimulate the discourse on social workers' political activity. For this purpose, implications for social work education, practice, and research are outlined in the final section.
\end{abstract}

Keywords: civic participation, international comparison, macro social work, policy practice, political participation, political social work 


\section{Introduction}

Social work and politics have always had a close interaction. Political processes shape the organizational contexts and social conditions within which social work operates, and it is social workers who, in their everyday practice, implement measures decided by social policymakers. Social work always acts as an authority downstream of social policy: it fills gaps in the system retrospectively and contributes expertise at the grassroots level, drawing attention to new social problems and structural deficits (Lane \& Pritzker, 2018). This reality can and should be leveraged to enable social work to act as an authority upstream of social policy. Social workers have the practical knowledge and social justice motivation to make them ideal participants in the political process.

The tense relationship between politics and social work has existed since social work's inception. The commitment of social workers' political involvement in Switzerland can be traced to the women's movement and its influence in organizing against poverty in the 19th century. In 1896, for example, more than 5,000 women's associations of over 100,000 women worked assiduously to promote charitable giving at the individual level (Epple \& Schär, 2015; Matter, 2011). This trajectory parallels the development of Charitable Organization Societies in the US (Stern \& Axinn, 2017). While the trajectories for the development of direct services are similar between the two countries, Switzerland lagged the US in joining the international settlement movement. In the US, the charitable giving and settlement house arms of social work both began in the late 19th century and was shaped by significant social, economic, and political contexts, including the Gilded Age, both World Wars, The New Deal, McCarthyism, and the Civil Rights Movement (Stern \& Axinn, 2017). Switzerland's foray into the development of settlement houses and social reform as complements to individual services and advocacy for the professionalization of social work training began after the First World War. While few of the Swiss Settlements have existed since, the commitment of social workers to social reform is evidenced by its enshrinement in their professional code of ethics (Epple \& Schär, 2015; Matter, 2011).

The Swiss professional association of social workers, AvenirSocial (2010), includes a call to initiate and accompany political processes among its ethical principles. This position is in line with the attitude of the IFSW (2014), which explicitly understands "policy formulation and analysis and advocacy and political interventions" as social work tasks. The National Association of Social Workers in the United States, for its part, illustrates this political understanding of social work in its Code of Ethics by demanding that "social workers should engage in social and political action" (NASW, 2017, p. 30). The growing consensus in professional ethics discourse that social work has a political mandate brings another question to the fore: To what extent this political mandate is proclaimed by academics and 
representatives of professional associations and accepted and carried out by social workers at the grassroots level? This question has so far received little attention in empirical social work research so that corresponding discussions tend to take place on a normative level and lack an international comparative perspective. The present article addresses these gaps with the two studies from Switzerland and the United States. The samples are compared with each other, particularly regarding the extent of political participation by social workers and the explanatory power of different factors influencing political activities.

In this study, political activity is understood broadly as the voluntary political participation as defined by Verba et al. (1995) as all activities that have "the intent or effect of influencing government action-either directly by affecting the making or implementation of public policy or indirectly by influencing the selection of people who make those policies. By voluntary activity we mean participation that is not obligatory - no one is forced to volunteer - and that receives no pay or only token financial compensation" (pp. 38-39). Accordingly, this study does not focus on policy practice - understood as the policy engagement of social workers as part of their job (Gal \& Weiss-Gal, 2015) — but examines the voluntary political participation of social workers.

In order to identify factors affecting the political activity of social workers this study draws on the Civic Voluntarism Model (CVM) developed by Verba et al. (1995) as a methodological framework (see also Schlozman et al., 2018). The CVM assumes that political activity is influenced by the following three central factors: First, available resources in the form of time, money, and knowledge influence whether and how easily a person can become politically active. Second, the degree of political engagement in the form of political efficacy, political interest, or political ideology influences how a person wants to participate in policymaking. And third, recruitment networks act as "triggering factor[s]" (Verba et al., 1995, p. 273) by encouraging people to engage in political activities or by providing them with important skills and knowledge on policy processes.

\section{Literature Review}

Since its development in 1995, the CVM has been validated across many studies. Political social work researchers use and extend this standard explanatory model to further understand social workers' political engagement and political attitudes (e.g., Gal \& Weiss-Gal, 2015; Kindler, 2021a; Schwartz-Tayri, 2021). Previous empirical studies on political social work drawing on the CVM can be divided into the following three different research focus areas.

Much research focuses on the political commitment of social work students. These studies show that students agree to a great extent with the political mandate of the profession, are strongly left-wing oriented/liberal (Kindler \& Kulke, 2022; 
Kulke \& Schiffert, 2018), and are more involved in politics than the overall population (Lane et al., 2018). Like professional social workers, social work students primarily participate in passive activities not requiring significant time, energy, or resources rather than in active forms of political engagement. Macro-oriented students tend to be more involved in policy than their micro-oriented fellow students (Ostrander et al., 2018). Pre-post-design studies indicate that policy practice training programs and social welfare policy seminars are helpful in increasing political interest (Bernklau Halvor, 2016), a sense of both internal and external political efficacy (Ostrander et al., 2017), as well as the planned future political activity of the participants (Lane et al., 2018).

Studies focusing on trained social workers consistently show that they are more involved in politics than the overall population, especially in conventional forms of participation such as voting (Hamilton, 1998). However, it appears that in their political involvement, social workers tend to carry out activities that require less time, energy, or resources, which means that they are more involved in passive (e.g., reading the news) than inactive (e.g., taking part in demonstrations) engagement (Ostrander, 2016). Most studies show that social workers are politically left-wing oriented/liberal and agree to a high extent with a political mandate of the profession (Kindler \& Hobi, 2021; Kulke et al., 2022; Ostrander, Kindler \& Bryan, 2021). Analyzing influencing factors has been shown that years since graduation and age (Hamilton, 1998), membership in political and professional organizations (Gewirtz-Meydan et al., 2016; Ritter, 2006; Weiss-Gal \& Gal, 2020), political interest (Kulke \& Schmidt, 2019), political courses throughout social work training (Kohlfürst \& Kulke, 2019), internal and external political efficacy (Ritter, 2006), political knowledge and skills (Gewirtz-Meydan et al., 2016), strength of identification with a party or ideology (Hamilton, 1998; Ritter, 2006), agreement with political social work (Kindler, 2021a), organizational support of political engagement, as well as professional status (Weiss-Gal \& Gal, 2020) have an impact on political participation.

A third focus of previous CVM-based scholarship has been on social workers who are engaged as elected politicians. However, these studies are less frequent than studies on the political commitment of social workers in general. This can be attributed to the fact that very few social workers run for office. For example, out of 2,821 elected officials at the state level in Switzerland, only $40(1.5 \%)$ have a background in social work (Amann \& Kindler, 2021a). So, how might this proportion be increased? Studies have found that social work training is crucial to potential candidates. 63 percent of the politicians surveyed by Lane (2008) said that their academic studies prepared them well for a political career. The support and the mobilization of professional and political networks also influence the pursuit of elected office (Amann \& Kindler, 2021b; Binder \& Weiss-Gal, 2021; Lane, 2008). In addition, most elected officials who are social workers come from families of origin in which policy was frequently discussed. In addition to the nuclear family, other 
role models and/or politicizing events (e.g., queer-feminist movements) were mentioned, by which social workers were significantly influenced in their political socialization. Furthermore, it could be shown that a commitment at the party-political level is only possible with experience over time. The surveyed politicians reported that it is not always easy to reconcile party-political obligations and professional activity without sufficient time to address both. In some cases, loyalty conflicts arise, especially when a political commitment is explicitly not approved by superiors (Amann, 2017).

\section{Purpose of the Study}

Although existing studies provide meaningful insight into social workers' political activity, the literature review reveals essential gaps in this area of research. While social workers have been characterized as more politically active than the overall population by extant research, passive forms of political activity are clearly preferred over active political engagement. This can be seen, amongst others, in the minimal involvement of social workers running for and holding elected office (Kindler \& Amann, 2022a). Thus, the question of how this passivity can be transformed into activity comes to the fore. In this context, it makes sense to delve more deeply into existing research findings and closely examine factors influencing political activity.

A further research gap exists in international comparative research that examines influencing factors. Most published work on the political activity of social workers in different countries is descriptive and focuses on individual countries in Europe (Gal \& Weiss-Gal, 2013, 2017; Kindler, 2021b). Gray et al. (2002) published the only known cross-national comparative article on political participation in Australia, South Africa, and New Zealand. Only one study (Ostrander, Kindler \& Bryan, 2021) was found that compared social workers in Switzerland and the United States, but it did not address the factors influencing their political activity. This article aims to fill this gap by identifying factors impacting political participation among Swiss and US social workers. Therefore, the purpose of this study is to consider the differences between Swiss and US social workers' political activity and the differences concerning the variables affecting their political activity. To measure these differences, the following three research questions based on the assumptions of the Civic Voluntarism Model will be addressed:

1. To what extent are Swiss and US social workers politically active?

2. Which variables influence the political activity of Swiss and US social workers?

3. Are there any differences between Swiss and US social workers concerning variables affecting their political activity? 


\section{Methods}

The data described here were collected from Swiss and US social work participants through two separate voluntary self-administered, self-report online surveys that included scales and items that could be used for comparison. Institutional review boards at both institutions approved the studies.

\section{Research Instruments}

The instrument used to measure political engagement consists of a 14-item scale adapted from Rome and Hoechstetter (2010) and further developed by Kindler (2019) and Ostrander et al. (2017). This overall Political Activity Scale (PAS) consists of an Active Subscale that includes "active" behaviors such as contacting an elected official, working for pay or volunteering for a political campaign, or civil disobedience. The PAS also consists of a Passive Subscale, including "passive" behaviors such as voting on local, state, and federal levels, donating money, or discussing current policy. Participants were asked how often they have participated in each of these activities, with the following possible responses: never (0), rarely (1), sometimes (2), often (3), very often (4). The Political Activity Scale $(\alpha=.851)$ is comprised of 14 items with a score range of $0-56$. The Active Subscale $(\alpha=.788)$ has 7 items with a score range of $0-28$. The Passive Subscale $(\alpha=.748)$ is comprised of 7 items with a score range of $0-28$.

To operationalize internal and external political efficacy the survey included a four-item scale developed for the American National Election Survey (ANES), later refined by Niemi et al. (1991). The internal political efficacy scale consisted of two items $(\alpha=.61)$ : First, "How well do you understand the important political issues facing our country?" Response options were: not well (0), slightly well (1), moderately well (2), very well (3), extremely well (4); second, "I feel I could do as good a job in public office as most other people." Response options for this second item were: strongly disagree (0), disagree (1), neither agree nor disagree (2), agree (3), strongly agree (4). The external political efficacy scale consisted of two items as well $(\alpha=.56)$ : "How much do public officials care what people like you think?" and "How much can people like you affect what the government does?" For both items, response options were: not at all (0), a little (1), a moderate amount (2), a lot (3), a great deal (4). For the internal and external political efficacy scale, the two respective, above-described items were added together to form a total score ranging from 0 (low) to 8 (high political efficacy).

The study used three items to measure the political influence of parents during the youth of respondents. First, participants were asked how often they had political discussions with their parents during their youth. Possible answers were never (0), rarely (1), often (2), and very often (3). Second, it was asked whether the 
mother was politically active during the youth of the participant, and third, the same question was asked concerning the father, with only two possible answer categories: yes (1) or no (2).

To measure the membership in mobilization networks, respondents were asked to indicate their memberships in a trade union and a professional social work association. Possible answers were yes (1) or no (0).

A dichotomous item was used to determine the extent to which respondents were stimulated to engage in political activity as part of their studies. Participants were asked the following question: "Would you say that during your social work education, you were encouraged to be politically active?" Response options were yes (1) or no (0).

\section{Data Collection and Sampling}

The first author developed the Swiss questionnaire in 2017 and 2018 based on a broad review of the literature and after several consultations with the second author. The questionnaire consisted of 77 closed- and open-ended items and was applied in the official Swiss languages of French, German, and Italian. In Switzerland, social workers do not have the opportunity to get a license. In addition, there is no reliable data about the actual number of social workers working in the country (AvenirSocial, 2017), but the number is estimated at about 90,000 (Kindler, 2019). As a result of having no list of social workers in Switzerland, random sampling could not be used as a data collection strategy. Instead, convenience and snowball sampling methodologies were used to distribute the questionnaire through employers, professional associations, Universities, alumni organizations, Facebook groups, and personal contacts. An estimated 40,000 social workers have received the invitation to participate (Kindler, 2019). Of the 2,245 individuals who started the survey, 1,824 participants $(81 \%)$ finished the questionnaire between May and July 2018. For this article, all students and other participants who did not hold a bachelor's degree in social work have been excluded; 1,242 social workers remain in the sample.

The second author developed the US questionnaire in 2017 based on findings from his dissertation work, a review of the literature, and modifications by political social work experts. The questionnaire consisted of 85 closed- and openended questions and was applied in English. In 2017 and 2018, the professional boards of all 50 states and the District of Columbia were contacted, and a data file including the email addresses of social work licensees was requested. In the end and after multiple inquiries, 24 states (approximately 221,327 licensed social workers in total) provided data files. After cleaning the list of erroneous email addresses, 133,656 were identified as eligible to participate in the study. Using a random number generator in Microsoft Excel, one-third of these licensed social workers, or 
44,552, were selected for the sample. These email addresses were organized into panels of 5,000, and every member of the sample was emailed on four separate occasions between June and October 2018. For this study, 3,033 licensed social workers participated.

To compare the political activity and the corresponding influencing factors between US $(n=3,033)$ and Swiss social workers $(n=1,242)$, both above-described datasets were merged in the Statistical Package SPSS (Version 28). For the 4,275 participants, the mean age was $46(M=45.7, S D=14.1)$, and the sample was predominantly female (76\%). 98 percent of US social workers are registered to vote, and 96 percent in the Swiss sample are Swiss citizens, which entitles them to vote. See table 1 for more demographic details.

Table 1: Descriptive Demographic Data

\begin{tabular}{lcccc}
\hline Variable & \multicolumn{2}{c}{ Swiss sample } & \multicolumn{2}{c}{ US sample } \\
\cline { 2 - 5 } & $n$ & $\%$ & $n$ & $\%$ \\
\hline Gender & & & & \\
$\quad$ Male & 424 & 34.14 & 400 & 17.03 \\
$\quad$ Female & 810 & 65.22 & 1,916 & 81.57 \\
$\quad$ Other & 8 & 0.64 & 33 & 1.40 \\
Age & & & & \\
$\quad<31$ & 364 & 29.31 & 220 & 9.54 \\
$31-40$ & 383 & 30.84 & 557 & 24.15 \\
$41-50$ & 213 & 17.15 & 469 & 20.34 \\
$51-60$ & 224 & 18.03 & 460 & 19.95 \\
$>60$ & 58 & 4.67 & 600 & 26.02 \\
Membership & & & & \\
$\quad$ Trade union & 246 & 19.81 & 351 & 14.82 \\
Professional association & 608 & 48.95 & 976 & 32.18 \\
$\quad$ No memberships & 552 & 44.44 & 1,205 & 50.89 \\
\hline
\end{tabular}

\section{Data Analysis}

In order to answer research question 1, descriptive statistics was used to describe the extent of the examined social workers' political participation on the Political Activity Scale and on the Active and the Passive Subscales. To compare Swiss and US social workers' political activity, independent sample t-tests were conducted. As for research question 2, correlation analysis was applied to explore the correlation between the Political Activity Scale and all independent variables (see 'Research Instruments' section and Table 3). To test how much of the variance in political activity can be explained by the influencing factors, a hierarchical multiple regression analysis was conducted, each for the Swiss and the US sample 
separately. Finally, to answer research question 3, the regression analyses' Betaand standardized Beta-coefficients were compared and interpreted.

\section{Results}

\section{Political Activity}

Table 2: Political Activities of Swiss and US social workers

\begin{tabular}{lcccc}
\hline Political Activity & \multicolumn{2}{c}{ Swiss sample } & \multicolumn{2}{c}{ US sample } \\
\cline { 2 - 5 } & $M$ & $S D$ & $M$ & $S D$ \\
\hline Active Subscale & & & & \\
Contacted elected official & 1.00 & 1.24 & 1.56 & 1.05 \\
$\quad$ Volunteer with interest group & 0.95 & 1.36 & 1.36 & 1.15 \\
Participate in political rallies, protests & 0.96 & 1.17 & 1.32 & 1.10 \\
Voice opinion to media markets & 0.49 & 0.96 & 0.98 & 1.12 \\
Volunteer for a political campaign & 0.69 & 1.09 & 0.80 & 1.02 \\
Civil disobedience & 0.23 & 0.71 & 0.62 & 0.93 \\
Work for pay for a political campaign & 0.04 & 0.27 & 0.13 & 0.52 \\
Passive Subscale & & & & \\
Vote federal & 3.31 & 1.16 & 3.75 & 0.74 \\
$\quad$ Vote state & 3.27 & 1.14 & 3.45 & 0.97 \\
Vote local & 3.21 & 1.17 & 3.19 & 1.14 \\
$\quad$ Discuss current policy & 3.22 & 0.85 & 2.46 & 0.97 \\
Boycott products & 1.49 & 1.41 & 2.31 & 1.05 \\
Donate money & 0.90 & 1.15 & 1.21 & 1.19 \\
$\quad$ Use social media to engage in politics & 1.04 & 1.27 & 1.09 & 1.25 \\
\hline
\end{tabular}

Note. $0=$ never, $1=$ rarely, $2=$ sometimes, $3=$ often, $4=$ very often

There was a statistically significant difference in overall political participation measured on the Political Activity Scale (Range 0-56, $M=23.0, S D=8.8$ ). US social workers $(M=24.2, S D=8.5, n=2,372)$ have been found to be more politically active than Swiss social workers $(M=20.8, S D=8.9, n=1,242)$, $t(3612)=11.308, p<.001$. There was a statistically significant difference in political participation measured on the Active Subscale (Range 0-28, $M=6.0, S D=$ $4.8)$ as well. US social workers $(M=6.8, S D=4.6, n=2,446)$ have been found to be more politically engaged in active behaviors than Swiss social workers $(M=4.4$, $S D=4.6, n=1,242), t(3686)=15.005, p<.001$ (see Table 2 for single activities). There was also a statistically significant difference in political participation measured on the Passive Subscale (Range $0-28, M=17.1, S D=5.0$ ). US social workers ( $M=17.4, S D=4.7, n=2,415)$ have been found to be more politically engaged in passive behaviors than Swiss social workers $(M=16.4, S D=5.3, n=1,242)$, 
$t(2247)=5.606, p<.001$ (see Table 2 for single activities). Levene's test indicated unequal variances $(F=27.758, p<.001)$, so degrees of freedom were adjusted from 3655 to 2247.

\section{Influencing Factors}

Correlation analysis reveals that all analyzed predictor variables are positively and significantly correlated with political activity. Table 3 shows that the strongest correlation exists between internal political efficacy and political activity $(r=.52, p<$ $.001)$. Another strong relationship has been found between political discussions with parents and political activity $(r=.27, p<.001)$.

Table 3: Descriptive Statistics and Correlations for Study Variables

\begin{tabular}{lcccc}
\hline Variable (Range) & $n$ & $M$ & $S D$ & 1 \\
\hline 1. Political Activity (0-56) & 3,614 & 23.04 & 8.79 & - \\
2. Internal political efficacy (0-8) & 4,021 & 4.56 & 1.85 & $.52^{* * *}$ \\
3. External political efficacy (0-8) & 4,018 & 3.42 & 1.54 & $.17^{* * *}$ \\
4. Political discussions with parents (0-3) & 3,955 & 1.70 & 0.94 & $.27^{* * *}$ \\
5. Mother politically active (0/1) & 3,914 & .38 & .48 & $.20^{* * *}$ \\
6. Father politically active (0/1) & 3,895 & .45 & .50 & $.16^{* * *}$ \\
7. Union membership (0/1) & 3,610 & .17 & .37 & $.12^{* * *}$ \\
8. Professional SW association membership (0/1) & 4,275 & .37 & .48 & $.19^{* * *}$ \\
9. Educational encouragement for political activity $(0 / 1)$ & 3,588 & .57 & .50 & $.05^{*}$ \\
\hline
\end{tabular}

${ }^{*} p<.05 .{ }^{* *} p<.01 .{ }^{* * *} p<.001$

Table 4 shows the impact of internal and external political efficacy, political discussions with parents, mothers' and fathers' political activity during youth, union and professional association memberships, and educational encouragement on social workers' political activity. The examined independent variables in the regression models explain 43 percent of the variance of political activity in the Swiss subsample $(F(8,1169)=108.88, p<.001)$ and 27 percent in the US subsample $(F(8,2146)=100.40, p<.001)$.

For the Swiss respondents, the findings reveal that internal political efficacy $(\beta=.50, \mathrm{p}<.001)$, political discussions with parents during youth $(\beta=.12, p<$ $.001)$, union membership $(\beta=.15, p<.001)$, professional social work association membership $(\beta=.16, p<.001)$, and educational encouragement $(\beta=.08, p<.001)$ positively predict their political activity. For the US respondents, the findings reveal that internal $(\beta=.38, p<.001)$ and external political efficacy $(\beta=.13, p<.001)$, political discussions with parents during youth $(\beta=.15, p<.001)$, and professional social work association membership $(\beta=.12, p<.001)$ positively predict their political activity. 
Table 4: Hierarchical Regression Results for Political Activity Scale

\begin{tabular}{|c|c|c|c|c|c|c|c|c|c|c|c|c|}
\hline \multirow[t]{2}{*}{ Variable } & \multicolumn{6}{|c|}{ Swiss sample $(n=1,242)$} & \multicolumn{6}{|c|}{ US sample $(n=2,148)$} \\
\hline & $B$ & $95 \% \mathrm{CI}$ & SE $B$ & $\beta$ & $R^{2}$ & $\Delta R^{2}$ & $B$ & $95 \% \mathrm{CI}$ & SE $B$ & $\beta$ & $R^{2}$ & $\Delta R^{2}$ \\
\hline Step 1 & & & & & .35 & $.35^{* * *}$ & & & & & .22 & $.22^{* * *}$ \\
\hline Constant & $11.94^{* * *}$ & {$[10.87,13.02]$} & 0.55 & & & & $10.64^{* * *}$ & {$[9.49,11.81]$} & 0.59 & & & \\
\hline Internal political efficacy & $2.37^{* * *}$ & {$[2.18,2.56]$} & 0.10 & $.60^{* * *}$ & & & $2.23^{* * *}$ & {$[2.03,2.43]$} & 0.10 & $.42^{* * *}$ & & \\
\hline External political efficacy & $-0.30^{*}$ & {$[-0.55,-0.05]$} & 0.13 & $-.06^{*}$ & & & $0.87^{* * *}$ & {$[0.65,1.09]$} & 0.11 & $.15^{* * *}$ & & \\
\hline Step 2 & & & & & .37 & $.02^{* * *}$ & & & & & .26 & $.04^{* * *}$ \\
\hline Constant & $10.04^{* * *}$ & {$[8.76,11.32]$} & 0.65 & & & & $8.95^{* * *}$ & {$[7.77,10.14]$} & 0.60 & & & \\
\hline Internal political efficacy & $2.24^{* * *}$ & {$[2.05,2.43]$} & 0.10 & $.57^{* * *}$ & & & $2.04^{* * *}$ & {$[1.84,2.24]$} & 0.10 & $.39^{* * *}$ & & \\
\hline External political efficacy & $-0.30^{*}$ & {$[-0.54,-0.05]$} & 0.13 & $-.06^{*}$ & & & $0.79^{* * *}$ & {$[0.57,1.01]$} & 0.11 & $.14^{* * *}$ & & \\
\hline Political discussions with parents & $1.20^{* * *}$ & {$[0.61,1.78]$} & 0.30 & $.11^{* * *}$ & & & $1.38^{* * *}$ & {$[1.01,1.74]$} & 0.19 & $.16^{* * *}$ & & \\
\hline Mother politically active & $1.20^{*}$ & {$[0.14,2.26]$} & 0.54 & $.06^{*}$ & & & 0.35 & {$[-0.39,1.1]$} & 0.38 & .02 & & \\
\hline Father politically active & 0.50 & {$[-0.45,1.45]$} & 0.49 & .03 & & & $0.71^{*}$ & {$[0.01,1.42]$} & 0.36 & $.04^{*}$ & & \\
\hline Step 3 & & & & & .42 & $.05^{* * *}$ & & & & & .27 & $.01^{* * *}$ \\
\hline Constant & $8.85^{* * *}$ & {$[7.59,10.11]$} & 0.64 & & & & $8.40^{* * *}$ & {$[7.22,9.59]$} & 0.61 & & & \\
\hline Internal political efficacy & $1.98^{* * *}$ & {$[1.79,2.17]$} & 0.10 & $.50^{* * *}$ & & & $2.02^{* * *}$ & {$[1.82,2.22]$} & 0.10 & $.38^{* * *}$ & & \\
\hline External political efficacy & -0.23 & {$[-0.47,0.01]$} & 0.12 & -.05 & & & $0.74^{* * *}$ & {$[0.53,0.96]$} & 0.11 & $.13^{* * *}$ & & \\
\hline Political discussions with parents & $1.26^{* * *}$ & {$[0.70,1.82]$} & 0.29 & $.12^{* * *}$ & & & $1.33^{* * *}$ & {$[0.97,1.69]$} & 0.19 & $.16^{* * *}$ & & \\
\hline Mother politically active & 1.02 & {$[-0.01,2.04]$} & 0.52 & .05 & & & 0.36 & {$[-0.38,1.1]$} & 0.38 & .02 & & \\
\hline Father politically active & 0.21 & {$[-0.71,1.12]$} & 0.47 & .01 & & & $0.71^{*}$ & {$[0.01,1.41]$} & 0.36 & $.04^{*}$ & & \\
\hline Union membership & $3.30^{* * * *}$ & {$[2.29,4.31]$} & 0.52 & $.15^{* * *}$ & & & 0.08 & {$[-0.78,0.95]$} & 0.44 & .01 & & \\
\hline Association membership & $2.88^{* * *}$ & {$[2.07,3.69]$} & 0.41 & $.16^{* * *}$ & & & $2.15^{* * *}$ & {$[1.53,2.78]$} & 0.32 & $.13^{* * *}$ & & \\
\hline Step 4 & & & & & .43 & $.01^{* * *}$ & & & & & .27 & .00 \\
\hline Constant & $8.02^{* * *}$ & {$[6.68,9.36]$} & 0.68 & & & & $8.29^{* * * *}$ & {$[7.09,9.49]$} & 0.61 & & & \\
\hline Internal political efficacy & $1.97^{* * *}$ & {$[1.79,2.16]$} & 0.10 & $.50^{* * *}$ & & & $2.02^{* * *}$ & {$[1.82,2.22]$} & 0.10 & $.38^{* * *}$ & & \\
\hline External political efficacy & $-0.27^{*}$ & {$[-0.50,-0.03]$} & 0.12 & $-.05^{*}$ & & & $0.73^{* * *}$ & {$[0.51,0.94]$} & 0.11 & $.13^{* * *}$ & & \\
\hline Political discussions with parents & $1.26^{* * *}$ & {$[0.70,1.82]$} & 0.28 & $.12^{* * *}$ & & & $1.32^{* * *}$ & {$[0.96,1.69]$} & 0.19 & $.15^{* * *}$ & & \\
\hline Mother politically active & 0.96 & {$[-0.06,1.98]$} & 0.52 & .05 & & & 0.35 & {$[-0.39,1.08]$} & 0.38 & .02 & & \\
\hline Father politically active & 0.18 & {$[-0.74,1.09]$} & 0.46 & .01 & & & 0.70 & {$[-0.01,1.4]$} & 0.36 & .04 & & \\
\hline Union membership & $3.31^{* * *}$ & {$[2.31,4.32]$} & 0.51 & $.15^{* * *}$ & & & 0.08 & {$[-0.79,0.94]$} & 0.44 & .01 & & \\
\hline Association membership & $2.77^{* * *}$ & {$[1.97,3.58]$} & 0.41 & $.16^{* * *}$ & & & $2.13^{* * *}$ & {$[1.5,2.76]$} & 0.32 & $.12^{* * *}$ & & \\
\hline Educational encouragement & $1.53^{* * *}$ & {$[0.67,2.39]$} & 0.44 & $.08^{* * *}$ & & & 0.40 & {$[-0.22,1.02]$} & 0.32 & .02 & & \\
\hline
\end{tabular}

Note. $C I=$ confidence interval [lower limit, upper limit].

${ }^{*} p<.05 .{ }^{* *} p<.01 .{ }^{* * *} p<.001$. 


\section{Comparing Swiss and US social workers}

Table 4 allows a comparison of the Swiss and US subgroups of social workers concerning the variables predicting their political activity. Internal political efficacy is the strongest predictor for political activity both in the Swiss $(\beta=.50, p<.001)$ and the US subsample $(\beta=.38, p<.001)$. External political efficacy generates contradicting results: While in the Swiss group this variable negatively predicts political activity $(\beta=-.05, p<.026)$, it positively predicts the political activity of US social workers $(\beta=.13, p<.001)$. Political discussions with parents during youth is another important influencing factor of Swiss $(\beta=.12, p<.001)$ and US respondents' $(\beta=.15, p<.001)$ political activity. While union membership positively predicts Swiss social workers' political activity $(\beta=.15, p<.001)$ this variable has a nonsignificant effect on US social workers. Professional social work association, however, is positively predicting both Swiss $(\beta=.16, p<.001)$ and US social workers' political activity $(\beta=.12, p<.001)$. Educational encouragement for political activity only predicts the actual political activity of Swiss $(\beta=.08, p<.001)$ while not of US respondents.

\section{Discussion}

The impetus for this article was to understand how a relatively young social work profession in Switzerland with an ethical mandate to engage in politics would compare to a more mature US profession. As the authors suspected, US social workers engage in political activities at significantly higher levels than Swiss social workers. When considering the political engagement activities deemed "active" and "passive" (Ostrander et al., 2017; Rome and Hoechstetter, 2010), US social workers are more engaged in both categories than their Swiss colleagues. The only activity that Swiss social workers engage in at a higher level is discussing current policy. This result could, amongst others, be related to the controversial presidency of Donald Trump and the polarizing nature of US society when the survey was administered in 2018. The socio-political atmosphere in the US could make people feel less comfortable discussing their ideas and beliefs for fear of negative interactions with friends, family, and colleagues (Dimock \& Gramlick, 2021).

In line with previous research (Binder \& Weiss-Gal, 2021; Hamilton, 1998; Kohlfürst \& Kulke, 2019; Kulke \& Schmidt, 2019; Ritter, 2006; Weiss-Gal \& Gal, 2020) the findings of this study indicate that the political activity of social workers is strongly influenced by the political influence of their parents during youth, membership in a professional social work association, as well as by a strong internal political efficacy. Comparing these factors affecting Swiss and US social workers' political engagement two differences can be identified. US social workers are not significantly affected by educational encouragement through social work education 
and union membership. According to the Organization for Economic Cooperation and Development (2021), union membership was higher in Switzerland (14.4\%) as compared to the United States (10.1\%), which could help explain why this variable was not significant among US social workers. Also, social workers overwhelmingly work in micro practice and lack collective bargaining opportunities in the US. Unions have been replaced by a multitude of professional associations and groups that support and reinforce a micro practice orientation. In the United States, it is well documented that macro-oriented scholars, for example, have accused social work education of neglecting macro practice and focusing its energies on micro training (Ostrander, Kelly \& Carl-Stannard, 2021; Schwartz-Tayri et al., 2021; Specht \& Courtney, 1994). This may provide further evidence why educational encouragement was not significant among US social workers.

The findings of this study have implications for social work education as well as social work practice. For social work educators it is interesting to see that political efficacy, as found by this study, has the strongest impact on social workers' engagement in politics and therefore is maybe an area where social work education can have the most significant impact. When higher levels of political efficacy are present in social workers, studies report greater engagement in voluntary or paid activities that directly impact the political system and, by extension, policy actors. There is limited research conducted on current students and graduates of social work programs to understand better how social work education can affect students' political participation. Some knowledge about this topic can be found in research conducted with social work faculty (Gal \& Weiss-Gal, 2017; Pritzker \& Lane, 2014; Wolk et al., 1996). These studies report meager participation in policy or political work when surveying field-based faculty. Also, similar barriers were identified in this body of scholarship: Students do only request political placements to a low extent. Additionally, field faculty and students question whether political placements meet accreditation requirements and help students to find a job in the field of social work after graduation. To tackle these uncertainties a concrete social work accreditation standard for political content should be defined and included across program levels and options in social work curricula. Existing teaching material on policy practice and political participation in social work (e.g., Burzlaff, 2022; Jansson, 2018; Ritter 2019) can be used to strengthen the political part of the profession in curricula, and supports students to develop political efficacy, knowledge, and skills required to successfully engage on the political level. For social work practice it might be of interest that this study identified the membership in social work associations as an important factor influencing the political activity of social workers in both Switzerland and the United States. Professional associations and employer organizations should take this as a starting point to think about possibilities to further strengthen and support the political engagement of their members and employees. Although, professional organizations have been identified 
as relevant political recruitment networks by previous scholarship (e.g., Kindler \& Amann, 2022b; Kindler \& Kulke, 2022; Weiss-Gal \& Gal, 2020), there is still little knowledge on how they actually help their members to participate on the political level (see Beimers, 2015; Hartnett et al., 2005; Scanlon et al., 2006). Accordingly, future research should go beyond the examination of individual political behavior and analyze organizational strategies in facilitating their members' end employees' political engagement. Finally, it seems promising to broaden the scope and to not only focus on the voluntary political activity but also on policy practice - understood as policy engagement of social workers as part of their job (Gal \& Weiss-Gal, 2013) - as well as on the link between political activity and policy practice.

\section{Study Limitations}

The study is constrained by several limitations. While the sampling process in the US study has been randomized, the Swiss group consists of a non-probabilistic convenience sample. In addition, the US sample is twice the size of the Swiss sample. While not all US participants answered every question, the Swiss participants were forced to answer all questions in the survey. The second major limitation of this study is using a cross-sectional self-report measure. Also, there may be reliability challenges that could be attributable to the political environment of the 2018 midterm election when the US survey was administered. The 2018 midterm cycle was strongly impacted by the 2016 Presidential election and ran counter to the expected outcome based on polling. In addition, the former president's unconventional approach to policy commanded media cycles and the electorate's attention. This included engaging many who would typically not be as attentive to political commentary and processes and hyperawareness for those who would otherwise engage normally with politics. Finally, there is a potential limitation in comparing and interpreting the US to Swiss participants' political participation because of different electoral systems, cultures, and political structures (Norman \& Hintze, 2005). Likewise, variation exists in requirements for social workers to be licensed and in the normative understanding of social work practice.

\section{Conclusion}

Political activity is an integral part of the social work profession in Switzerland and the US and is embedded in both professional Codes of Ethics. This study adds to the paucity of studies that compare social workers policy engagement internationally. Further, this study highlights the importance of political influence of parents, membership in a professional social work association as well as political efficacy as significant factors influencing social workers' political activity. Additionally, it 
is critically important to impart the skills and tools necessary to engage in the political sphere through social work education and activities of social work organizations. This is paramount because social workers have the power to influence policies that impact service users' lives. Social work programs should therefore offer opportunities to educate students and practitioners on basic civic knowledge and require building political engagement skills. Both micro and macro social work practitioners and students should learn these critically important skills, which would effectively socialize them to the professions' foundation of the social justice mandate and prepare them to engage not only in individual casework but also to bring about change on the structural level.

\section{References}

Amann, K. (2017). Sozialarbeitende in der Politik. Eine qualitative Untersuchung der Politisierungsprozesse von Sozialarbeitenden, die sich aktiv parteipolitisch engagieren [Master's thesis, FHS St.Gallen, University of Applied Sciences]. Soziothek. https://www.soziothek.ch/sozialarbeitende-in-der-politik

Amann, K., \& Kindler, T. (2021b). Social workers in politics - A qualitative analysis of factors influencing social workers' decision to run for political office. European Journal of Social Work. Advance online publication. https://doi.org/10.1080/13691457.2021.1977254

Amann, K., \& Kindler, T. (Eds.) (2021a). Sozialarbeitende in der Politik. Biografien, Projekte und Strategien parteipolitisch engagierter Fachpersonen der Sozialen Arbeit. Frank \& Timme.

AvenirSocial (2010). Swiss social work professional code of ethics. AvenirSocial.

AvenirSocial (2017). Die nationale Kampagne von AvenirSocial: Eine Ausbildung in Sozialer Arbeit bürgt für Qualität. Grundlagendokument. https://avenirsocial.ch/wpcontent/uploads/2018/12/Grundlagendokument_Ausbildungskampagne_AvenirSocial_2017_DE_web.pdf

Beimers, D. (2015). NASW involvement in legislative advocacy. Journal of Policy Practice, 14(3-4), 256-274.

https://doi.org/10.1080/15588742.2015.1017685

Bernklau Halvor, C. D. (2016). Increasing social work students' political interest and efficacy. Journal of Policy Practice, 15(4), 289-313. https://doi.org/10.15760/etd.565

Binder, N., \& Weiss-Gal, I. (2021). Social workers as local politicians in Israel. British Journal of Social Work. Advance online publication. https://doi.org/10.1093/bjsw/bcab219

Burzlaff, M. (2022). Selbstverständnisse Sozialer Arbeit. Individualisierungen Kontextualisierungen - Policy Practice (2nd ed.). Beltz Juventa. 
Dimock, M. \& Gramlick, J. (2021, January 21). How American changed during Donald Trumps presidency. Pew Charitable Trust. https://www.pewresearch.org/2021/01/29/how-america-changed-during-donald-trumps-presidencyl

Epple, R., \& Schär, E. (2015). Spuren einer anderen Sozialen Arbeit. Kritische und politische Soziale Arbeit in der Schweiz 1900-2000. Seismo.

Gal, J., \& Weiss-Gal, I. (2015). The 'Why' and the 'How' of policy practice: An eight-country comparison. British Journal of Social Work, 45, 1083-1101. https://doi.org/10.1093/bjsw/bct179

Gal, J., \& Weiss-Gal, I. (Eds.) (2017). Where academia and policy meet. A crossnational perspective on the involvement of social work academics in social policy. Policy Press.

Gewirtz-Meydan, A., Weiss-Gal, I., \& Gal, J. (2016). Social workers' policy practice in non-profit human service organisations in Israel. British Journal of Social Work, 46, 1890-1908. https://doi.org/10.1093/bjsw/bcv138

Gray, M., van Rooyen, C. C., Rennie, G., \& Gaha, J. (2002). The political participation of social workers: a comparative study. International Journal of Social Welfare, 11, 99-110. https://doi.org/10.1111/1468-2397.00204

Hamilton, D. H. (1998). Factors affecting social workers' political participation: Ressources, professional associations and perceived efficacy [Doctoral Dissertation, Virginia Commonwealth University]. VCU Scholars Compass. https://doi.org/10.25772/5Y0F-7N12

Hartnett, H., Harding, S., \& Scanlon, E. (2005). NASW chapters: Directors' perception of factors which impede and encourage active member participation. Journal of Community Practice, 13(4), 69-83. https://doi.org/10.1300/J125v13n04 05

International Federation of Social Workers [IFSW] (2014). Global definition of social work: Practice. https://www.ifsw.org/what-is-social-work/global-definition-of-social-work

Jansson, B. S. (2018). Becoming An Effective Policy Advocate. From Policy Practice to Social Justice (8th ed.). Cengage Learning.

Kindler, T. (2019). Sozialarbeitspolitik. Eine empirische Untersuchung der politischen Aktivität von Fachpersonen der Sozialen Arbeit in der Schweiz [Master's thesis, FHS St.Gallen, University of Applied Sciences]. Soziothek. https://www.soziothek.ch/sozialarbeitspolitik

Kindler, T. (2021a). Sozialen Wandel gestalten - Einflussfaktoren auf die politische Aktivität von Fachpersonen und Studierenden der Sozialen Arbeit in der Schweiz. In: A. Dischler, \& D. Kulke (Eds.), Politische Praxis und Soziale Arbeit. Theorie, Empirie und Praxis politischer Sozialer Arbeit (pp. 163-180). Barbara Budrich. https://doi.org/10.2307/j.ctv25c4z79.11 
Kindler, T. (2021b). Politische Aktivität von Sozialarbeitenden. Einblicke in ein sich dynamisch entwickelndes Forschungsfeld. In A. Dischler \& D. Kulke (Eds.), Politische Praxis und Soziale Arbeit. Theorie, Empirie und Praxis politischer Sozialer Arbeit (pp. 87-108). Barbara Budrich. https://doi.org/10.2307/j.ctv25c4z79.8

Kindler, T., \& Amann, K. (2022a). Strategies of social workers' policy engagement - A qualitative analysis among Swiss social workers holding elected office [Manuscript submitted for publication]. School of Social Work, Eastern Switzerland University of Applied Sciences.

Kindler, T., \& Amann, K. (2022b). Politisches Engagement von Fachpersonen der Sozialen Arbeit in der Schweiz. Eine Frage der Mobilisierung? In M. Gehrlach, M. von Bergen \& K. Eiler (Eds.), Zwischen gesellschaftlichem Auftrag und Wettbewerb - Sozialmanagement und Sozialwirtschaft in einem sich wandelnden Umfeld (pp. 55-71). Springer VS.

Kindler, T., \& Hobi, L. (2021). Begründungsmuster für einen politischen Auftrag Sozialer Arbeit. In S. Elsen, U. Nothdurfter, C. Lintner, A. Nagy \& L. Trott (Eds.), Social work in a border region: 20 years of social work education at the Free University of Bozen-Bolzano (pp. 39-50). Bozen-Bolzano University Press. https://doi.org/10.13124/9788860461889_1_3

Kindler, T., \& Kulke, D. (2022). Politicized social work future - A trinational comparison of social work students' political participation in Austria, Germany, and Switzerland [Manuscript submitted for publication]. School of Social Work, Eastern Switzerland University of Applied Sciences.

Kohlfürst, I., \& Kulke, D. (2019). Politische Einstellungen und Partizipation von Studierenden der Sozialen Arbeit in Österreich. Soziale Arbeit in Österreich, 2, 13-19.

Kulke, D., \& Schiffert, T. (2018). "Student und Politik". Ergebnisse einer Befragung von Studierenden der Sozialen Arbeit. Forum Sozial, 2, 17-23.

Kulke, D., \& Schmidt, J. (2019). Der politische Auftrag Sozialer Arbeit in der Praxis - Empirische Ergebnisse. In M. Köttig \& D. Röh (Eds.), Soziale Arbeit in der Demokratie - Demokratieförderung in der Sozialen Arbeit (pp. 301313). Barbara Budrich.

Kulke, D., Kindler, T., \& Kohlfürst, I. (2022). Politische Partizipation im Kontext Sozialer Arbeit - ein trinationaler Blick auf politische Einstellungen und Beteiligungsformen von Studierenden der Sozialen Arbeit in Österreich, Deutschland und der Schweiz. Annual Review of Social Work and Social Pedagogy in Austria, 4, 144-162.

Lane, S. R. (2008). Electing the right people: A survey of elected social workers and candidates [Doctoral dissertation, University of Connecticut]. OpenCommons@UConn. https://opencommons.uconn.edu/dissertations/AAI3351337 
Lane, S. R., \& Pritzker, S. (2018). Political social work. Using power to create social change. Springer.

Lane, S. R., Ostrander, J. A., \& Smith, T. R. (2018). Politics is social work with power: training social workers for elected office. Social Work Education, 37(1), 1-16. https://doi.org/10.1080/02615479.2017.1366975

Matter, S. (2011). Der Armut auf den Leib rücken. Die Professionalisierung der Sozialen Arbeit in der Schweiz (1900-1960). Chronos.

National Association of Social Workers [NASW] (2017). Code of ethics of the national association of social workers. NASW.

Niemi, R. G., Craig, S. C., \& Mattei, F. (1991). Measuring internal political efficacy in the 1988 National Election Study. The American Political Science Review, 85(4), 1407-1413. https://doi.org/10.2307/1963953

Norman, J., \& Hintze, H. (2005). A sampling of international practice variations. International Social Work, 48(5), 553-567. https://doi.org/10.1177/0020872805055319

Organization for Economic Cooperation and Development (2021, December 21). Trade union database. https://stats.oecd.org/Index.aspx?DataSetCode=TUD

Ostrander, J. A. (2016). To participate or not to participate, that is the question: A critical phenomenological study of clinical social workers and their political participation [Doctoral dissertation, University of Connecticut]. OpenCommons@UConn. https://opencommons.uconn.edu/dissertations/1296

Ostrander, J. A., Bryan, J., Sandler, A., Nieman, P., Clark, M., Loveland, E., \& Smith, T. R. (2018). The political participation of first year social work students: Does practice specialization matter? Journal of Sociology \& Social Welfare, 45(3), 39-59. https://scholarworks.wmich.edu/jssw/vol45/iss3/4

Ostrander, J. A., Kelly, K., Carl-Stannard, P. (2021). Integrating macro-micro practice. Encyclopedia of Social Work. Oxford University Press. https://doi.org/10.1093/acrefore/9780199975839.013.1447

Ostrander, J. A., Kindler, T., \& Bryan, J. (2021). Using the Civic Voluntarism Model to compare the political participation of US and Swiss social workers. Journal of Policy Practice and Research, 2(1), 4-19. https://doi.org/10.1007/s42972-020-00020-z

Ostrander, J. A., Lane, S. R., McClendon, J., Hayes, C., \& Smith, T. R. (2017). Collective power to create political change: Increasing the political efficacy and engagement of social workers. Journal of Policy Practice, 16(3), 261-275. https://doi.org/10.1080/15588742.2016.1266296

Pritzker, S., \& Lane, S. R. (2014). Field note - Integrating policy and political content in BSW and MSW field placements. Journal of Social Work Education, 50(4), 730-739. https://doi.org/10.1080/10437797.2014.947905 
Ritter, J. A. (2006). An empirical study evaluating the political participation of $l i-$ censed social workers in the United States: A multi-state study [Doctoral dissertation, University of Texas]. University of Texas repositories. http://hdl.handle.net/2152/2629

Ritter, J. A. (2019). Social work policy practice. Changing our community, nation, and the world (2nd ed.). Cognella Academic Publishing.

Rome, S. H., \& Hoechstetter, S. (2010). Social work and civic engagement: The political participation of professional social workers. Journal of Sociology \& Social Welfare, 37(3), 107-129. https://scholarworks.wmich.edu/jssw/vol37/iss3/7

Scanlon, E., Hartnett, H., \& Harding, S. (2006). An analysis of the political activities of NASW state chapters. Journal of Policy Practice, 5(4), 41-54. https://doi.org/10.1300/J508v05n04 04

Schlozman, K. L., Brady, H. E., \& Verba, S. (2018). Unequal and Unrepresented: Political Inequality and the People's Voice in the New Gilded Age. Princeton University Press.

Schwartz-Tayri, T. M. (2021). The Willingness of Social Work Students to Engage in Policy Practice: The Role of Personality Traits and Political Participation Predictors. British Journal of Social Work, 51(7), 2381-2398. https://doi.org/10.1093/bjsw/bcaa065

Schwartz-Tayri, T. M., Malka, M., Moshe-Grodofsky, M., \& Gilbert, N. (2021). Integrating Micro and Macro Practice: An Evaluation of the Policy Advocacy Course. Journal of Social Work Education, 57(3), 464-477. https://doi.org/10.1080/10437797.2020.1713271

Specht, H., \& Courtney, M. E. (1994). Unfaithful angels: How social work has abandoned its mission. Free Press.

Stern, M. \& Axinn, J. (2017). Social welfare: A history of the American response to need $\left(9^{\text {th }}\right)$ ed.). Pearson.

Verba, S., Schlozman, K. L., \& Brady, H. E. (1995). Voice and equality: Civic voluntarism in American politics. Harvard University Press.

Weiss-Gal, I., \& Gal, J. (2020). Explaining the policy practice of community social workers. Journal of Social Work, 20(2), 216-233.

https://doi.org/10.1177/1468017318814996

Wolk, J. L., Pray, J. E., Weismiller, T., \& Dempsey, D. (1996). Political practica: Educating social work students for policymaking. Journal of Social Work Education, 32(1), 91-100. https://doi.org/10.1080/10437797.1996.10672287 